\title{
FUNDAMENTALISME ISLAM: TELAAH TERHADAP PEMIKIRAN POLITIK HIZBUT TAHRIR INDONESIA (HTI)
}

\author{
Ana Sabhana Azmy \\ Ilmu Politik FISIP UIN Syarif Hidayatullah, Jakarta, Indonesia \\ E-mail: anashabana.azmi@uinjkt.ac.id
}

\begin{abstract}
ABSTRAK. Tulisan ini mendiskusikan pemikiran politik Hizbut Tahrir Indonesia (HTI) sebagai bagian dari gerakan fundamentalisme Islam di Indonesia. HTI adalah gerakan dakwah yang berkembang di Indonesia di awal tahun 1980-an dengan pengaruh pendahulunya, yaitu Hizbut Tahrir. Terdapat tiga pertanyaan yang dicoba untuk dijawab dalam tulisan ini. Pertama, bagaimana pemikiran politik HTI terhadap demokrasi? Kedua, bagaimana konteks khilafah Islamiyyah yang diinginkan oleh HTI? Ketiga, bagaimana kiprah HTI dalam perpolitikan Indonesia? Penelitian ini dilakukan melalui bentuk hasil pemikiran dengan studi literatur, menggunakan data yang diperoleh melalui bahan kepustakaan yang relevan, baik buku ataupun dokumen-dokumen pendukung. Selain itu, wawancara via online juga dilakukan terhadap juru bicara HTI. Kesimpulan dari tulisan ini adalah bahwa fundamentalisme Islam dalam pemikiran HTI, dapat dilihat dari cara pandang terhadap demokrasi yang bagi mereka adalah sebagai sistem yang kufur dan sama sekali tidak mempunyai hubungan dengan Islam. HTI menyatakan bahwa sistem demokrasi itu bertentangan dengan hukum-hukum Islam. Khilafah Islamiyyah yang diinginkan oleh HTI adalah tegaknya kembali kekhilafahan yang merupakan lambang supremasi politik Islam, yang itu menjadi titik point atas Islam. Sedangkan peran HTI dalam politik di Indonesia dapat dilihat dari persentuhan mereka dengan pemerintah, diterbitkannya buletin Al-Islam yang berisi isu HAM, Amerika versus umat Islam, Keindonesiaan hingga pentingnya khilafah. HTI juga pernah mengirimkan surat pada Presiden Susilo Bambang Yudhoyono dalam rangka mengajak pada penegakan sistem khilafah di Indonesia.
\end{abstract}

Kata kunci: Fundamentalisme; HTI; Khilafah; Demokrasi

ABSTRACT. This paper discusses the political thinking of Hizbut Tahrir Indonesia (HTI) as part of the Islamic fundamentalism movement in Indonesia. HTI is a da'wah movement that developed in Indonesia in the early 1980s with the influence of its predecessor, namely Hizbut Tahrir. There are three questions that are tried to be answered in this paper. First, how is HTI's political thinking on democracy? Second, what is the context of the Islamic caliphate desired by HTI? Third, how is HTI doing in Indonesian politics? This research was conducted through the form of thought-provoking studies of literature, using data obtained through relevant library materials, either books or supporting documents. In addition, online interviews were also conducted with HTI spokesmen. The conclusion of this paper is that Islamic fundamentalism in HTI's thinking can be seen from the perspective of democracy which for them is a kufr system and has absolutely no relationship with Islam. HTI states that the democratic system is against Islamic laws. The Islamic Khilafah that HTI wants is the re-establishment of the Caliphate which is a symbol of Islamic political supremacy, which is the point of view of Islam. Meanwhile, HTI's role in politics in Indonesia can be seen from their contact with the government, the publication of the Al-Islam bulletin which contains issues of human rights, America versus Muslims, Indonesia and the importance of the caliphate. HTI has also sent a letter to President Susilo Bambang Yudhoyono in order to invite the enforcement of the caliphate system in Indonesia.

Key words: Fundamentalism; HTI; Khilafah; democracy

\section{PENDAHULUAN}

Dalam perdebatan teoretik, belum ada kesepakatan terminologis untuk menunjuk pada sikap kelompok muslim tertentu yang melakukan penolakan pada bentuk sosial yang ada dan mengupayakan penerapan pada suatu bentuk tersendiri yang memiliki basis nilai keagamaan. Beberapa term yang digunakan seperti Islam militan, Islam anti liberal, ektremisme Islam, Islam skripturalis, revivalisme
Islam, Islam radikal dan Islam fundamentalis. Fundamentalisme yang ada hingga hari ini, diidentikkan pada kalangan Islam tradisional, dan pada sudut pandang sejarah disebut kelompok yang konservatif/mempertahankan nilai lama. Istilah tersebut adalah kata lain dari kelompok revivalis, dimana secara umum karakter gerakan revivalisme adalah; (1) memiliki sikap dan rasa prihatin mendalam pada degenerasi sosio-moral masyarakat muslim, (2) menyampaikan peringatan pada masyarakat 
mulism untuk kembali menyandarkan pemahaman dan praktik keagamaannya pada sumber yang dapat dipercaya seperti al-Qur'an dan Hadits. Juga agar tidak mengacu pada praktik takhayul, bid'ah, khurafat dalam nilai agama, (3) menyampaikan peringatan untuk masyarakat mulism agar "membuang" teologi fatalisme, guna meraih kemajuan, (4) memberi peringatan pada masyarakat muslim agar melakukan kebaruan melalui jihad ketika dirasa perlu. (Sumbulah, 2009).

Azyumardi Azra dalam buku Pergolakan Politik Islam sebagaimana dikutip oleh Sumbulah (2009) bahwa fundamentalisme disebut sebagai format ekstrem atas gejala revivalisme, dan juga menghadirkan kesulitan untuk dibedakan secara rigid. Sebagai bentuk ekstrim dari revivalisme, tidak hanya dilihat dari meningkatnya konteks keislaman secara intensif yang mempunyai orientasi ke dalam. Namun juga, ke luar yang berfokus pada gerakan bersifat komunal dan masif. Kata-kata yang dikembangkan kelompok tersebut diantaranya adalah al-Qur'an merupakan kalam Ilahi yang wajib dimengerti secara literal; al-Qur'an dan Hadits sudah menyiapkan sebentuk regulasi dan doktrin haram-halal untuk prilaku seseorang dan masyarakat. Titik krusial dan sentral agama untuk kelompok tersebut adalah hal-hal yang wajib dijalankan secara riil pada semua bentuk kehidupan. Bentuk tersebut bukan hanya ibadah ritual yang contohnya adalah shalat, puasa, zakat dan lainnya. Tetapi harus menyentuh perihal sosial, budaya, ekonomi dan politik (Sumbulah, 2009).

Menurut Bassam Tibi sebagaimana dikutip oleh Badrussyamsi dalam bukunya, ia tidak mengartikan fundamentalisme Islam sebagaimana Kristen. Tibi menjelaskan bahwa fundamentalisme Islam didefinisikan sebagai sebuah gerakan yang dapat menjadi tantangan besar bagi politik dunia, keamanan dan stabilitas. Gerakan mereka adalah gerakan politisasi agama yang agresif untuk mencapai tujuan-tujuan non agama. (Badrussyamsi, 2015).

Salah satu gerakan yang dapat dilihat dalam konteks fundamentalisme adalah Hizbut Tahrir. Gerakan ini dijelaskan sebagai gerakan Islam kekinian yang mempunyai pengaruh besar pada dunia Islam. Nama HT dalam bahasa arab memiliki makna "hizbun" (partai) dan "tahriir" (kemerdekaan), yang kemudian digabungkan menjadi partai kemerdekaan. HT menganggap selain konsep khilafah yang mereka gunakan, yang lainnya bertentangan dengan ajaran Islam (Jahroni and Jamhari, 2004).

Arubusman sebagaimana dikutip oleh Hendropriyono (2009) dalam bukunya, menyatakan bahwa fundamentalisme Islam wajib dilihat sebagai sebuah respon pada hal-hal yang mengikuti skup modernitas, yang kemudian dilihat sudah jauh keluar dari nilai agama Islam. Kecondongan tersebut adalah gejala ideologis yang merupakan reaksi pada gejala ideologis juga yang bisa dikatakan sebagai akibat dari adanya persentuhan dengan konteks budaya. Fundamentalisme Islam juga bisa dihubungkan dengan kondisi geopolitik internasional, juga apa yang tersirat dibaliknya. Penggunaan cara kekerasan yang dominan digunakan oleh fundamentalisme Islam, jika dilihat pada konteks geopolitik global, masyarakat muslim di Timur Tengah ada pada kondisi yang tidak baik, secara sudut politik juga sudut ekonomi.

Banyaknya pemerintahan dari sebuah negara yang menjalani ketidakstabilan politik dikarenakan menjalankan sistem demokrasi, menjadi salah satu hal yang mendorong pada penyebaran fundamentalisme. Atas pandangan tersebut, maka kaum fundamentalis berkeyakinan bahwa ajaran Islam sudah lengkap, sempurna dan berangkat dari titik tolak kalimat tauhid, maka kemudian diterapkanlah langkah berikutnya dalam segala level kehidupan (Hendropriyono, 2009).

Gerakan fundamentalisme menggunakan ayat al-Qur'an untuk legisitmasi gerakan, diantaranya adalah melalui QS Al-Maidah ayat 44, bahwasanya Tuhan menyampaikan pada pihak yang tidak memakai hukum Allah, maka masuk pada golongan kafir, fasik, dan zalim. Banyak penafsiran dan konteks dari ayat tersebut, namun gerakan fundamentalis menyatakan ayat ini adalah keabsahan gerakan mereka, hingga membuat kontra di khalayak publik. Bagi kaum radikal dan fundamentalis, sesuatu yang bertentangan dengan syariat Allah adalah salah, dan kemudian mereka mengartikan demokrasi sebagai sesuatu yang bertentangan dengan syariat Allah (Hendropriyono, 2009).

Salah satu gerakan fundamentalisme yang dapat dilihat adalah pada potret hadirnya Hizbut Tahrir Indonesia (HTI). Para aktivis HTI merupakan generasi yang terdidik secara 
Islami melalui halaqah-halaqah kajian Islam yang terstruktur, dan memiliki latar belakang pendidikan perguruan tinggi. Dalam konteks referensi pendirian dan karya tulisnya, HTI menjadikan para founding fathers nya sebagai referensi yang utama dan sah bagi referensi dakwah HT. Tradisi pemikiran yang kuat di HT, ditunjukkan dengan berbagai tulisan yang dipublikasikan oleh para aktivisnya. Dengan demikian, dapat dilihat bahwa anggota-anggota HT adalah orang-orang yang berpendidikan dan memiliki dasar pengetahuan keislaman yang berkembang di Timur Tengah (Minardi, 2008).

Dawam Rahardjo (2010) menjelaskan bahwa di Indonesia, kelompok fundamentalis diwakili oleh organisasi-organisasi baru seperti; Majelis Mujahidin Indonesia, Front Pembela Islam, Hizbut Tahrir Indonesia, dan Partai Keadilan Sejahtera, serta partai-partai Islam pada umumnya. Kelompok fundamentalis mempunyai tujuan mendirikan negara Islam, menghidupkan kembali kekhilafahan Islam sedunia dan pelaksanaan syari'at Islam melalui formalisasi atau pelembagaan dalam hukum positif. Ciri lain dari kelompok fundamentalisme adalah penggunaan kekerasan, meski cara ini ditolak oleh HTI dan PKS (Rahardjo, 2010).

Dalam buku Gerakan Sosial Islam Hizbut Tahrir, Sitti Jamilah (2020) menjelaskan bahwa HTI berbeda dengan PKS, sebab PKS lebih bersifat terbuka bagi non muslim, sedangkan HTI tidak menerima keanggotaan dari kalangan non muslim. Tiap anggota HTI diwajibkan untuk menggunakan ideologi dan sistem yang ada dalam Islam. HTI tidak melihat latar belakang suku dan madzhab dari anggotanya, melainkan hanya memandang anggotanya adalah orang Islam dan menjalankan segala sesuatu yang mempunya dasar hukum Islam. Untuk penyebaran ideologi HTI, diwajibkan bagi tiap kader yang telah memiliki kapasitas dan jaminan (sumpah) kepada HTI. Tiap beberapa kader yang ditunjuk, akan diberi daftar beberapa orang yang harus didatangi untuk di follow up berbicara tentang khilafah, konsep keislaman dan lainnya. (Jamilah, 2020)

Di Indonesia, HTI menuliskan Pancasila dalam Anggaran Dasar/ Anggaran Rumah Tangga(AD/ART)nyasebagaidasar dariideologi mereka. Meski demikian, hal tersebut di nilai oleh Kementerian Hukum dan HAM tidak sejalan dengan kegiatan dan aktifitasnya yang dianggap bertentangan dengan landasan hukumnya. Kelompok HTI sebelumnya sudah tertulis pada Kementerian Hukum dan HAM (Kemenhukam) sebagai Badan Hukum Perkumpulan, nomer pendaftaran AHU-00282-60.10.2014 pada 2 Juli 2014 (M.merdeka.com, 2019). Jika melihat pada konteks ketidakpenerimaan HT/ HTI terhadap nilai-nilai Barat, nasionalisme dan juga bentuk pemerintahan di luar khilafah, maka terdapat sejumlah pandangan HTI yang bisa ditelaah dari salah satu pengimplementasian nilai-nilai Barat, yaitu Demokrasi. Untuk itu, pertanyaan penelitian dalam tulisan ini adalah: (1) Bagaimana pemikiran politik HTI terkait demokrasi? (2) Bagaimana konteks Khilafah Islamiyyah yang diinginkan oleh HTI? Dan (3) bagaimana kiprah HTI dalam perpolitikan di Indonesia?

Landasan teori yang dibangun adalah melihat pada pemikiran Held mengenai model demokrasi, Gunawan dan Sumbulah untuk melihat konteks khilafah Islamiyah HTI dan AnNabhani untuk melihat politik Hizbut Tahrir.

Held (2006) memaparkan bahwa pembangunan demokrasi diAthena telahmenjadi sumber utama atas inspirasi bagi pemikiran politik modern. Kesetaraan cita-cita politik di antara masyarakat, kebebasan, rasa hormat pada hukum dan keadilan, telah mempengaruhi pemikiran politik di Barat, meskipun ada beberapa gagasan sentral, misalnya, gagasan liberal modern bahwa manusia adalah 'individu' dengan 'hak', yang tidak bisa langsung dilacak ke Athena. Demokrasi Athena ditandai dengan komitmen umum pada prinsip kebajikan sipil, dedikasi kepada negara-kota republik dan subordinasi kehidupan pribadi untuk urusan publik dan kebaikan bersama (Held, 2006). Selain itu, Held (2006) juga menjelaskan bahwa Pericles pada konteks demokrasi Athena menunjukkan bahwa toleransi adalah penting, untuk membuat manusia menikmati dirinya dalam cara mereka masing-masing.

Sedangkan pada konteks khilafah Islamiyyah, Sumbulah menjelaskan bahwa HTI menyebut khilafah Islamiyyah sebagai sistem politik yang harus dijalankan lagi oleh masyarakat muslim. Runtuhnya kekhilafahan Utsmaniyyah pada Maret 1924, dinilai sebagai merupakan keberhasilan gemilang Barat dalam menganeksasi kekuatan politik Islam. Proses ini, menurut para aktifis HTI dilakukan Barat melalui 
tangan orang Islam sendiri, yaitu Musthafa Kemal Attaturk dengan konsep nasionalisme Turki. Nasionalisme bagi para aktifis HTI adalah ide yang absurd, tidak mengandung makna yang pasti. HTI menolak ideologi kapitalisme yang cenderung politis. Penyebaran paham-paham liberal dan sekuler sebagai "anak kandung" kapitalisme pun ditolak oleh HTI.(Sumbulah, 2009)

Terdapat dua pendekatan untuk memahami gejala fundamentalisme sebagaimana ditulis oleh Sumbulah dalam bukunya. Pendekatan tersebut adalah pendekatan obyektif dan pendekatan subyektif. Berdasarkan pandangan obyektivis, dimengerti bahwa fundamentalisme hadir sebagai reaksi dari teks agama yang memberikan pengesahan seperti itu. Pada pandangan subyektivis, meletakkan orang pada subyek yang aktif dalam mengekspos dirinya dengan kondisi luar. Untuk itu, bentuk fundamentalisme tidak dapat dimengerti hanya karena teks agama mengabsahkan demikian, tetapi perlu ditelaah pada bagaimana "dunia luar" adalah entitas yang ikut memberikan pengaruh pada seseorang ketika ada mekanisme internalisasi ajaran agama. Untuk itu, fundamentalisme dapat disebabkan karena adanya struktur sosial, ekonomi, serta politik. Oliver Roy (dalam Rahmat, 2008) menggunakan tema Islamisme, yang kemudian dipahami dan digunakan untuk mengidentifikasi potret kelompok Islam yang mengacu kepada usaha diberlakukannya syari'at Islam sebagai bentuk dasar untuk semua kegiatan kehidupan umat Islam. Roy menunjukkan sejumlah gerakan seperti Ikwanul Muslimin, Hizbut Tahrir, Jama'at Islami dan Islamic Salvation Front sebagai contoh dari kelompok tersebut.

Sedangkan Armstrong, Chourie, Kepel, Antoun, dan Steve Bruce menggunakan istilah fundamentalisme guna menjelaskan potret dari sebuah kelompok yang mau dan memiliki cita-cita mengubah nilai sosial yang sudah ada, dengan nilai sosial baru yang kemudian didasarkan pada nilai keagamaan (Sumbulah, 2009).

Terdapat sejumlah studi literatur yang penulis dapatkan atas penelitian terdahulu yang juga memiliki kesamaan topik dan sejenis. Pertama adalah tulisan dari Rahmat Nur Hakim yang berjudul "Gerakan Islam Politik Fundamentalis" yang mengacu pada fenomena Hizbut Tahrir Indonesia di Surabaya. Rahmat menjelaskan bahwa dalam memobilisasi gerakan mereka di era reformasi, HTI memakai bentuk organisasi gerakan sosial formal. Hal tersebut memiliki arti bahwa kegiatan di mobilisir melalui pola aktivisme gerakan, mengubah pemikiran kaum sekuler dan liberal di masyarakat melalui ide/pemikiran Islam. Lebih lanjut ia menjelaskan bahwa HTI Surabaya yang menjadi fokus penelitiannya, membuat bentuk pengkaderan yang mempunyai basis disiplin guna membuat aman gerakan dari penumpang bebas yang Cuma mengejar insentif. HTI Surabaya juga mengimplementasikan pola framing yang memposisikan agama Islam sebagai agama politik, dan Islam adalah ideologi yang mengatur seluruh sendi kehidupan masyarakat (Hakim, 2014).

Kedua, Tulisan dari Burhanuddin Muhtadi (2009) dengan judul "The Quests for Hizbut Tahrir in Indonesia”. Muhtadi men-jelaskan tentang sifat HTI di era pasca-Suharto dan kerangka ideologisnya. Ini kemudian akan menyelidiki bagaimana HTI, lebih dari kebanyakan kelompok Islam lainnya, mendapat manfaat dari runtuhnya rezim. Dalam penjelasannya, Muhtadi menggambarkan bahwa terdapat beberapa point sebagai alasan mengapa kelaziman HTI bisa dilihat tidak sejalan pada usaha untuk menjadikan demokrasi di Indonesia semakin teguh dan stabil. Pertama, tindakan HTI dalam menolak keras pikiran terhadap demokrasi yang dianut pemerintah, bisa menghadirkan kerawanan demokrasi yang bisa berujung pada demokrasi yang tidak stabil. Kelompok HTI tidak menggunakan kekerasan dalam menyebarkan pesan anti demokrasinya, tetapi HTI jelas mendapatkan keuntungan dari kebebasan yang diberikan oleh rezim demokrasi pasca Suharto. Kedua, HTI jelas tidak berhasil mentransformasikan kesetiaan politik umat menjadi negara bangsa. Ini telah mengkonfirmasi pernyataan Huntington bahwa umma dan negara bangsa adalah antitesis, karena yang terakhir membutuhkan subordinasi dari agama, kesukuan dan loyalitas primordial lainnya kepadanya. Ketiga, sanggahan HTI terhadap gagasan wilayah tertentu suatu negara telah menghasilkan konsekuensi yang lebih luas. Kedua konsep demokrasi dan bernegara tidak dapat dipisahkan. Negara bangsa adalah elemen dasar dari politik modern yang mendasari demokrasi. (Muhtadi, 2009) 
Ketiga, tulisan Azman (2018) yang berjudul "Gerakan dan Pemikiran Hizbut Tahrir Indonesia". Dalam tulisannya ia menjelaskan bahwa pikiran HTI dalam keagamaan adalah tidak menyetujui filsafat, hermeneutik, paham sekuler, kapitalis, serta sejumlah pemahaman atau pandangan yang tidak sejalan dengan Islam. Ini bisa dilihat dari sikap kritis HTI pada bentuk ekonomi dan kapitalisasi pendidikan serta potret pertanahan di Indonesia. Hal ini tidak lepas dari pandangan al-Nabhani yang menolak filsafat dan kemudian memerangi nilai/pandangan yang tidak sejalan dengan Islam. Bagi HTI, hal yang urgen dilakukan adalah mengubah masyarakat muslim ke arah perbaikan pemikiran Islam. Metode berfikir Islam bagi HTI dijadikan sebagai saqafah untuk model berfikir Islami (Azman, 2018).

Keempat, tulisan Sudarno Shobron dengan judul "Model Dakwah Hizbut Tahrir Indonesia". Ia menjelaskan bahwa HTI menerapkan pola Rasulullah SAW dalam melakukan dakwah, yang kemudian dibagi pada tiga bentuk; 1) Bentuk tatsqif (pembinaan dan pengkaderan). Dalam hal ini, dakwah dijalankan dengan pola meminta masyarakat untuk hadir ke rumah dan kemudian mengajak mereka untuk masuk Islam. 2) Bentuk tafa'ul (berhubungan) dengan masyarakat, agar mereka menjalankan nilai dan ajaran Islam yang baik. 3) Bentuk istilamu al-hukmi (menerima kekuasaan), guna menjalankan Islam dengan keseluruhan juga menyampaikan ajaran Islam pada seluruh masyarakat di dunia. Bentuk-bentuk dakwah tersebut menurut Sudarno oleh Hizbut Tahrir telah dijalankan pada posisi mencapai kekuasaan. Menurutnya, bentuk dakwah yang dijalankan Hizbut Tahrir adalah demi mencapai posisi kekuasaan. Dengan demikian, dakwah adalah trik politik mereka. (Shobron, 2014).

Hal yang menjadi pembeda tulisan ini dengan tulisan-tulisan lainnya di atas adalah bahwa penulis mencoba untuk mengangkat kiprah HTI dalam fenomena perpolitikan Indonesia dan konsep kesadaran politik yang dibangun oleh HTI. Sudut pandang dalam politik menurut HTI adalah tauhid Islam, yakni memandang pada Laa ilaaha illa Allah Muhammad Rasulullah. Seseorang yang mempunyai pemahaman politik akan membuat harus dirinya untuk berjuang melawan semua hal/paham yang tidak sejalan dengan pahamnya, dan memerangi seluruh pemahaman yang bertentangan dengan pemahamannya.

\section{METODE}

Penelitian ini adalah menggunakan metode kualitatif, dimana alasan penggunaan metode tersebut adalah dapat digunakan untuk menganalisa fenomena sosial dan politik yang lebih mendalami makna, dibanding data statistik dalam penelitian kuantitatif. Penelitian ini dilakukan melalui bentuk hasil pemikiran dengan riset kepustakaan/studi literatur terkait fundamentalisme Islam di Indonesia yang berfokus pada gerakan HTI, dan pemikiran mereka tentang demokrasi. Penelitian ini memakai jenis data sekunder, yaitu data yang didapat dengan mengakses bahan kepustakaan. Dengan demikian, pengumpulan data dilakukan dengan mencari bahan yang sesuai, baik buku atau pun jurnal. Penulis melakukan sejumlah pencarian literatur, baik dari buku, jurnal ataupun dokumen pendukung seperti website HTI/buletin dakwah HTI. Penulis juga mewawancarai seorang informan yang mengetahui tentang gerakan HTI, yaitu Ismail Yusanto, via online dan mengakses sejumlah referensi yang diberikan oleh narasumber terkait pemikirannya.

\section{HASIL DAN PEMBAHASAN}

\section{Demokrasi dalam Pandangan HTI}

Dalam upaya menggapai cita-cita nya untuk menyatukan kepemimpinan Islam pada satu wadah, maka seluruh ajaran dan nilai Barat tidak ditolerir oleh HTI, termasuk demokrasi. Pada pengertian demokrasi sebagaimana dikatakan oleh David Held (2006) ia menghimpun pengertian pandangan liberal dan tradisi Marxis untuk bisa mencapai makna demokrasi yang memberi dukungan pada prinsip dasar kebebasan: "orang seharusnya bebas dan setara dalam menentukan kondisi kehidupannya, yaitu mereka harus memperoleh hak yang sama, dan karena itu juga kewajiban yang sama dalam suatu kerangka pikir" (Sorensen, 2003).

Islam adalah agama yang mempunyai nafas akan nilai-nilai dari demokrasi. Jika demokrasi diartikan sebagai nilai yang menganut asas kebebasan dan kesetaraan serta pemenuhan hak antar masyarakat, maka Islam sudah lebih dahulu mengajarkan nilai tersebut. Salah satu nilai demokrasi yang ada dalam Islam ada musyawarah. Secara etimologi, lafadz al- 
syura dan al-musyawarah serta al-masyurah, adalah format dari kata kerja. Hakikat syura mengindikasikan potret nyata kedudukan yang sama serta posisi manusia yang sama, bebas dalam berpendapat, dan hak untuk melakukan kritik juga mengakui hak asasi manusia. Konsep musyawarah bisa menemukan cara untuk membuat manusia satu dan juga membuat golongangolongan/kelompok-kelompok bersatu, serta dapat pula bertukar pikiran dan berdiskusi (Sukardja \& Sudirman, 2005).

Hal berikutnya yang masuk dalam nilai demokrasi adalah adil. Bukan hanya keadilan, namun juga mengenai kebebasan. Kebebasan mengkritik sebagai contoh, adalah beriringan dengan nilai amar ma'ruf nahyi munkar (QS 3:104). Sebagaimana mengkritik, maka kebebasan lainnya juga dijamin dalam Islam. Sebagai contoh, kebebasan berpendapat selama bisa dipertanggungjawabkan secara moral dan hukum (QS 42:38), kebebasan berserikat dalam (QS 5:2) dan kebebasan dalam beragama dalam (QS 2:256). Al-Qur'an memberikan pula hak setara antara laki-laki dan perempuan pada konteks kebebasan mengkritik dan beroposisi terhadap pemerintahan yang sewenang-wenang (QS 9:71) (Kamil, 2013).

Argumen lainnya yang memperlihatkan bahwa Islam dan demokrasi adalah mendukung satu sama lain menurut Fahmi Huwaidi, yaitu menolak bentuk kediktatoran Namrudz dan Fir'aun (QS 2:258 dan 44:31). Dalam persoalan hak ekonomi, non muslim mendapatkan hak yang sama, karena al-Qur'an dalam membahas ekonomi tidak membedakan keduanya. Bahkan, dalam buku ar-Raudhah karya Imam Nawawi dijelaskan mengenai sah dan dibolehkannya wakaf kepada non muslim. Hal yang sama juga terjadi dalam persoalan kesetaraan hakhak publik untuk perempuan yang berawal dari kesalahan dalam memahami (QS 4:34). Hal ini dikarenakan bukan berarti laki-laki menjadi pemimpin perempuan karena jenis kelaminnya, melainkan karena nafkah dan kapabilitas saja.

Permasalahan kepemimpinan adalah masalah kapabilitas. Al-Qur'an memberi hak yang setara antara laki-laki dan perempuan pada konteks kebebasan mengkritik dan beroposisi terhadap pemerintahan yang sewenang-wenang (QS 9:71) (Kamil, 2013).

HTI berpandangan bahwa konsep demokrasi yang disosialisasikan pihak Barat pada negara Islam, adalah sistem yang kafir, tidak mempunyai keterkaitan sama sekali, langsung atau tidak. Menurut Ismail Yusanto sebagai jubir HTI, Islam memiliki pandangan-pandangan yang khas, yang berbeda dengan demokrasi Barat. Pertama, tentang kedaulatan. Islam memandang kekuasaan ada di tangan Allah. Islam memandang hanya Allah saja, tidak ada yang lain, tidak juga manusia atau rakyat, yang berhak sebagai syaari' (pembuat hukum- tasyri'). Kedua, bahwa kekuasaan di tangan ummat. Artinya tidak ada yang dapat tidak seorang pun dapat menjadi penguasa dalam masyarakat Islam, sampai mereka diinginkan umat, yang kemudian bisa dilihat dengan pengangkatan. Kekuasaan itu pun hanya untuk menjalankan syari'at Islam, bukan untuk menjalankan kedaulatan rakyat atau lainnnya. Ketiga, Hak Asasi Manusia. Jelas tidak ada paksaan untuk memasuki Islam. Namun, sekali orang masuk Islam, maka ia tidak bisa meninggalkan Islam sesukanya. Ia akan dikenakan hukum murtad dengan hukuman setimpal. Keempat, pengambilan keputusan. Dalam Islam, musyawarah bukanlah segalanya dalam cara pengambilan keputusan. Ini karena terdapat beberapa hal yang tidak bisa dikompromikan, seperti masalah keimanan dan syariat. Kelima, kekuasaan pemimpin (khalifah). Khalifah merupakan sosok yang memimpin masyarakat muslim, yang bisa dipilih dan diangkat ummat. Dia merupakan wakil dari masyarakat muslim dalam menjalankan syari'at Allah. Namun, dia ia juga memiliki hak untuk melegislasi hukum syara' dan menjadikan hukum syara' bagi seluruh kaum muslimin. Pembagian kekuasaan sebagaimana dalam sistem demokrasi, tidak relevan, bahkan bertentangan dengan Islam.

Keenam, majelis Ummah/Syura. Majelis ini adalah wakil ummah yang dipilih dari kalangan ummat guna menyampaikan pendapat ummat. Namun majelis ini bukan seperti lembaga legislatif, karena ia tidak menetapkan hukum (Yusanto, n.d.-a).

Demokrasi dikatakan memang tidak sealur dengan hukum-hukum Islam, global dan partikular. Perdebatan antara keduanya terlihat pada titik kehadirannya, akidah yang melahirkannya,basisyangmenjadidasarnya,juga sejumlah pikiran yang dihasilkan. Karenanya, masyarakat muslim tidak diperbolehkan sama sekali untuk menyentuh, apalagi menjalankan dan mensosialisasikan demokrasi. 
Bagi HTI, demokrasi menjadi penghambat bagi terwujudnya khilafah. Ada sejumlah point yang menjadi penghambat bagi HTI mewujudkan khilafah, dimana semua pointnya adalah dari Barat. Pertama, merebaknya pemikiran non Islami dan aktivitas ghazw al-fikr oleh musuh-musuh Islam. Ketika mengalami kelemahan bernalar, umat Islam dikuasai oleh pemikiran non Islami yang berpangkal pada nalar yang salah. Hal ini berakhir pada pikiran yang kosong, dan karenanya umat Islam harus dicerahkan dengan dakwah politik, dengan kata lain umat Islam harus disadarkan untuk membentuk khilafah. Kedua, adanya kurikulum dan metode operasional pendidikan yang diletakkan di Barat, baik di sekolah maupun perguruan tinggi. Akhirnya, produk pendidikan dari lembaga tersebut mempersepsikan Islam seperti yang diharapkan oleh Barat.

Ketiga, kontinuitas kurikulum pendidikan Barat. Hal ini menjadikan mayoritas lulusannya bergerak ke arah yang berlawanan dari Islam. Keempat, pengagungan terhadap ilmu-ilmu sosial, psikologi, dan pendidikan. Ilmu-ilmu tersebut digunakan sebagai solusi bagi masalah kehidupan manusia, dibanding al-Qur'an dan hadits.

Kelima, masyarakat muslim hidup di luar sistem masyarakat yang Islami, sehingga mengakibatkan pola fikir yang tidak Islami. Keenam, adanya disparitas yang tidak dekat antara masyarakatmuslim dan pola pemerintahan Islam, utamanya politik dalam pemerintahan dan strategi pengelolaan harta negara. Akibatnya, sebagian umat muslim mengalami kelelahan dan tidak bisa lagi mempersepsikan potret kehidupan Islam.

Ketujuh, adanya sistem pemerintahan di dunia Islam yang dibangun atas dasar demokrasi dan diterapkannya sistem kalitalisme sebagaimana di negara-negara Barat. Ini adalah salah satu yang mempersulit sistem khilafah. Kedelapan, kuatnya opini umum terkait nasionalisme, kesukuan, dan sosialisme serta keberadaan gerakan-gerakan politik yang dibangun atas dasar nasionalisme, sukuisme dan sosialisme. HT menilai bahwa ikatan kebangsaan itu salah, sebab ikatan tersebut merupakan ikatan emosional (Amin, 2012). Dengan demikian, HTI memandang bahwa penerapan dan akomodasi atas nilai-nilai Barat menyebabkan negara khilafah tidak dapat terbentuk.
Dalam menolak demokrasi, HTI mengikuti pendapat yang disampaikan pendahulunya di Timur Tengah, yaitu 'Abd al-Wadim Zallum. Baginya dan juga HTI, sistem demokrasi adalah sistem kufur/non Islam yang bertentangan dengan Islam. Argumennya antara lain adalah; karena konsep demokrasi merupakan buatan fikiran manusia, bukan buatan Allah; hal tersebut adalah bagian yang menyatu dari akidah pemahaman sekuler; pada ajaran nilai Islam, dalam Islam itu sendiri, kepemimpinan/ kekuasaan berada di tangan syari'at bukan pada rakyat; di dalam ajaran Islam pula, nilai yang mengacu pada mayoritas tidak mempunyai hal yang signifikan, karena hanya teks-teks syari'at; juga nilai kebebasan sebagaimana bebas untuk menjalankan agama dalam Islam, menurutnya tidak hadir, karena orang murtad yang tidak bertaubat dalam fiqh harus dihukum mati (Kamil, 2013).

Sejumlah keburukan demokrasi bisa disederhanakan sebagai berikut: (1) pihak yang menganut konsep demokrasi di negara Barat sudah tidak baik, dan ini karena konsep kebebasan berprilaku, (2) Sikap menjajah Barat melalui konsep demokrasi, menghadirkan sejumlah musibah dan penyusutan sejumlah bangsa yang terperangi dan mempunyai keterbelakangan, (3) konsep demokrasi dalam artian hakiki, tidak dapat diimplementasikan, (4) apa yang dikatakan oleh pihak yang mengikuti dan meyakini demokrasi adalah tidak dapat dipercaya dan membuat sesat ketika menyatakan bahwa legislatif merupakan representasi dari kemauan masyarakat luas, wujud secara politis keinginan general masyarakat kebanyakan, serta mewakili aspirasi masyarakat kebanyakan, (5) kecacatan dalam demokrasi dapat dilihat dari hal yang mempunyai koneksi atas kekuasaan, serta orang yang berkuasa. Adalah sebuah keanehan, ketika semua keburukan demokrasi telah terjadi, Barat ternyata mampu mewujudkan tempat untuk konsep atau nilai demokrasi yang tidak baik tersebut di negara-negara muslim. (Minardi, 2008).

\section{Perjuangan Khilafah Islamiyyah}

HT secara keseluruhan, demikian pula HTI mengembangkan dua elemen rakyat, kehidupan politik dan ekonomi. Disinilah dibentuk ekonomi Islam, politik Islam, negara Islam, dan berakhir di khilafah Islamiyah. HTI menyebut bahwa 
pendapat, pemikiran, dan hukum-hukum adalah paket yang satu, tidak dapat dibeda-bedakan. HTI menganggap pembentukan pribadi dan masyarakat harus diiringi dengan penegakan daulah Islamiyah atau khilafah Islamiyah. Khilafah merupakan konsep sentral dalam pemikiran HTI, dan menurut HTI Khilafah adalah sistem politik yang harus didirikan lagi oleh masyarakat muslim. Isu tegaknya khilafah menjadi ikon paling penting dalam gerakan HTI. Karenanya, dalam sejumlah publikasinya, HTI membahas bagaimana eksistensi khilafah itu ditinjau dari sisi-sisi sumber otoritatif, baik berupa teks-teks al-Qur'an maupun al-hadits. Dalam pembahasan HTI setidaknya ada delapan hadits yang bisa menjadi hujjah/alasan bagi HTI untuk wajib menegakkan khilafah. Diantaranya; hadits al-khilafah 'ala minhaj al-nubuwwah dan hadits tentang masuknya Islam di tiap rumah, hadits tentang kertas putih yang tergantung serta hadits tentang al-khilafah yang akan turun di bumi al-Quds, Palestina (Sumbulah, 2009).

Menurut HTI, tegaknya kembali kekhilafahan yang dipandang sebagai lambang supremasi politik Islam, menjadi titik point atas Islam. Ismail Yusanto menjelaskan bahwa bentuk khilafah Islamiyyah dapat mengakomodir nilai-nilai musyawarah, HAM, kebebasan berpendapat dan lainnya yang telah dijelaskan dalam pandangan khas demokrasi Islam menurut HTI sebagaimana dikemukakan oleh Yusanto sebagai informan penelitian.

Selain itu, bagi HTI nasionalisme merupakan ide yang absurd, tidak mengandung makna yang pasti dan juga merupakan ide yang kosong dari makna konkret. Menanggapi hal tersebut, HTI menjelaskan bahwa memang kecintaan terhadap Indonesia tidak boleh berkembang menjadi kecintaan yang berlebihan (nasionalisme chauvinis), dan kemudian menabrak batas-batas agama (Islam) (Yusanto, n.d.-b). Ditambahkan oleh HTI, bahwa kecintaan mereka terhadap Indonesia bukan kecintaan semu sebagaimana dilakukan oleh kelompok nasionalis sekuler, yang mengatakan cinta bangsa, namun membiarkan berbagai kebijakan yang pro asing.

Melalui verbal dan tulisan, HTI mewacanakan untuk perang melawan kapitalisme yang dinilai menjadi polisi dunia. Bagi mereka, menerima pluralisme agama, demokrasi, liberalisme yang semuanya merupakan akidah Barat yang kafir, sama artinya dengan menukar keislaman yang unggul dengan kekafiran yang dihinakan (Sumbulah, 2009).

Rakyat yang didambakan dan adalah keinginan HTI, ada pada bentuk ummah. Yaitu, rakyat yang berpedoman pada nilai-nilai kebudayaan, kesatuan serta nilai ketuhanan. Sama dengan Al-Nabhani, Ismail Yusanto sebagai jubir HTI memandang konsep nasionalisme adalah konsep yang berlawanan dengan sejarah. Menurutnya, nasionalisme membantah ketentuan dan lambat laun akan hilang, contohnya dengan semakin hilangnya batas negara, tidak memerlukan lagi KTP atau passport untuk menyeberang ke negara tertentu. Sebagai alternatif, maka HTI mengajukan konsep daulah Islamiyah atau khilafah Islamiyah. Dalam khilafah Islamiyah, maka kedaulatan tertinggi dipegang oleh seorang khalifah. Sosok tersebut dipilih lewat bentuk pemilihan yang nantinya dijalankan oleh Majelis Syura (Dewan Musyawarah). Khalifah tidak memisahkan rakyat dari kategori kelamin, bahwa perempuan juga dapat duduk di posisi-posisi yang spesifik jika mempunyai kapabilitas.

Menurut paparan Ismail Yusanto, sistem khilafah menyerupai demokrasi modern. Khalifah dan para anggota majelis syura berbagi kewenangan. Seorang Khalifah mempunyai kewenangan pemerintahan dan majelis syura mempunyai kewenangan legislatif. Khalifah berbarengan dengan majelis syura memilih dan menunjuk hakim. Pada kondisi yang memaksa, khalifah mempunyai kuasa pada konteks menetapkan atau mencari jalan keluar bagi masalah yang hadir atas warga negara (Jahroni \& Jamhari, 2004). Terdapat beda antara khilafah dengan demokrasi, yaitu khilafah mendasarkan pada agama dan demokrasi menurut HTI mendasarkan pada ketentuan rakyat.

Lebih jauh, implementasi khilafah Islamiyyah menurut Yusanto, bisa dilihat pada dua pokok; diimplementasikannya syariat dengan keseluruhan dan terwujudnya persatuan ummat. Pemahaman dari substansi pertama adalah bahwa ajaran Islam selain menyusun akan kehidupan personal, juga adalah perangkat yang mengatur hidup kerakyatan dan bernegara. Secara kehidupan personal, aktualisasi ajaran Islam pada masyarakat adalah tidak sama, ikut pada agama yang diyakini. Namun pada kehidupan personal, dan aspek ekonomi, sosial, 
politik dan lainnya, maka baik orang Islam atau bukan, harus ikut pada implementasi ajaran Islam. Sedangkan implementasi kedua, yang dibayangkan adalah bahwa satu waktu konsep khilafah diimplementasikan di sebuah pemerintahan, dan seorang khalifah akan membuat satu kawasan Islam disekitarnya pada khilafah. Untuk rangakaian ke arah itu, dapat dikukuhkan oleh khalifah yang kokoh tersebut, atau dapat pula dilakukan oleh masyarakat muslim yang ada di negara yang nantinya akan dibuat satu. (Redaksi, 2007).

Khilafah bagi HTI adalah instrumen utama untuk mendirikan masyarakat muslim. HTI melihat bahwa bentuk Islam yang dibangun oleh nabi dan para sahabat merupakan bentuk yang wajib dicontoh oleh masyarakat muslimin, dan bentuk tersebutlah kelak yang menggiring masyarakat muslim pada waktu kejayaan. Mengimani Islam secara kaffah adalah dasar ideologi HT (I). Awal mulanya HT adalah kelompok salaf yang mencoba kembali pada rujukan sumber Islam hakiki. Jika dicari, basis pemikiran HT akan sampai pada tokoh-tokoh pemikir Mesir yang ada di permulaan abad ke20, yaitu Muhammad Rasyid Ridha. Taqiyuddin sebagai pendiri HT mempunyai pengalaman menjadi murid langsung dengan sejumlah ulama yang adalah murid langsung Ridha. Untuk itu, bukan suatu yang ganjil jika selanjutnya ada konteks salaf dan puritanisme pada HT yang terlihat secara kasat mata dalam ciri-ciri fisik aktivis HT seperti memelihara jenggot atau penolakan terhadap praktik keagamaan seperti ritual tarekat yang dilakukan oleh kelompok Islam tradisional (Jahroni \& Jamhari, 2004).

\section{Kiprah HTI dalam Politik}

Menurut HTI, sebuah negara wajib dikenali dari konteks ideologi yang dimiliki, apa negara itu mengadopsi pemikiran atau tidak mengadopsi. Dunia pada sekarang ini dipimpin berdasarkan tiga pemikiran; Islam, komunisme dan kapitalisme. Menurut HTI, saat ini hanya Islam saja yang tidak mempunyai negara (AnNabhani, 2006).

Dalam wawancara Yusanto dengan Burhanuddin dari Tsaqafah, Ismail Yusanto menjelaskan bahwa pemikiran negara Islam memiliki banyak dasar, teologis, teoritis, secara sejarah dan secara rasional. Menurut Yusanto, jika ide negara Islam berdiri, maka ide tersebut memiliki kesanggupan untuk menjadikan satu sebanyak 1,4 miliar masyarakat muslim di penjuru dunia, dan hal tersebut adalah kuantitas besar. Ia melanjutkan bahwa gagasan uni Eropa yang tidak punya basis saja dapat terwujud, apalagi khilafah Islam. Menurutnya, jika tiap penguasa khilafah Islam berfikir layaknya para penguasa pemerintah-pemerintah Eropa saat ini, maka hal tersebut dapat diselesaikan dengan baik, meski misal tiap pemerintahan Islam mempunyai kepentingan nasional yang berbedabeda, sama seperti negara Eropa. Yusanto melihat bahwa mungkin setelah mata uang yang sama dan satu visa untuk semua negara, bisa jadi hadir pemilihan umum untuk semua negara Eropa dan lainnya. Ia mempertanyakan mengapa masyarakat muslim yang lebih punya dasar teologis dan historis tidak dapat demikian, mewujudkan dan menjaga persatuan ummat serta meneruskan masa kejayaan kekhilafahan Islam (Redaksi, 2007).

Oliver Roy sebagaimana dikutip oleh Imdadun Rahmat (2008) menjelaskan bahwa terdapat aktivisme politik-keagamaan yang ia sebut "Islamisme", yaitu sebuah aliran kekinian yang melihat Islam sebagai pemikiran politik. Islamisme sendiri ia katakan tidaklah monolitik dan senantiasa terombang ambing diantara kutub revolusi dan reformasi. Bagi kutub revolusioner, melakukan proses konversi masyarakat menjadi Islam harus dijalankan lewat kewenangan pemerintah melalui cara pengambilan kewenangan/kedaulatan lebih dulu. Golongan tersebut menggunakan strategi non kooperatif dengan pemimpin dan tidak menyetujui perangkat politik demokrasi yang dilihat tidak islami. Pada sisi lain, bagi kelompok reformasi, tindakan sosial dan politis yang ada memiliki tujuan melakukan Islamisasi lagi dari bottomup, yang kemudian akan menghadirkan khilafah Islam. Yang menjadikan beda kedua kelompok ini dijelaskan oleh Roy tidaklah dalam masalah kebutuhan khilafah Islam. Melainkan, pada jalan pencapaian serta perangai implementasinya terkait pada kewenangan. Mungkinkah kelakuan yang ditempuh adalah berusaha menghancurkan, sebagai lawan, kerjasama, atau mungkin acuh tak acuh terhadap politik. (Rahmat, 2008)

HTI termasuk dalam kutub revolusioner yang dijelaskan di atas. Kutub tersebut meliputi Organisasi Pembebasan Islam di Mesir dan Yordania, Takfir 
HTI juga berpendapat bahwa bagi umat Islam, pola pikir dalam politik merupakan Akidah Islam, yaitu pola pikir Laa ilaaha illa Allah Muhammad Rasulullah. Jika seseorang mempunyai kesadaran politik, maka ia mengharuskan diri agar masuk pada upaya melakukan perlawanan untuk seluruh kecenderungan yang tidak sama dengan kecenderungannya, serta melakukan perlawanan atas pengertian yang tidak sama dengan pengertiannya. Kesadaran politik menurut HTI tidak saja milik para elit politik dan ideolog, melainkan bersifat umum dan memang harus demikian. Penegakan politik pada kelompok masyarakat muslim wajib diimplementasikan dalam capaian yang luas, dikarenakan penegakan politik akan menciptakan kesadaran politik pada kelompok masyarakat muslim, lalu kemudian selalu menciptakan elit-elit politik yang pintar. (An-Nabhani, 2006).

Di Indonesia sendiri, HTI mempunyai peran dan juga persentuhan dengan pemerintah. Sebagai contoh, pada tahun 2010, HTI dalam tulisan-tulisannya di Bulletin Al-Islam, yang merupakan sebuahbuletinterbitan HTI, menuliskan bahwa mereka mengembalikan persoalan HAM, Amerika versus umat Islam, keindonesiaan hingga persoalan labelisasi halal-haram, dengan urgensi berdirinya khilafah. Selain itu, untuk menyatakan bahwa penegakan khilafah adalah hal penting, maka HTI menggelar pertemuan khilafah yang bersifat Internasional di tanggal 28 Mei 2000 dan pertemuan kedua di tanggal 12 Agustus 2007. HTI juga dalam surat terbukanya, meminta Presiden Susilo Bambang Yudhoyono untuk mencanangkan khilafah di bumi Indonesia (Amin, 2012). Dalam potret demikian terlihat bahwa HTI tidak menutup diri dari politik, bahkan mencoba untuk menjaga kedekatan dan terbuka dengan pemerintahan. Sebagaimana dalam paparan di atas, bahwa pada beberapa kegiatannya, HTI justru mengundang para tokoh Indonesia untuk menjadi narasumber kegiatan.

Meski turut andil dalam perpolitikan Indonesia, namun HTI bukanlah partai politik. Hal ini dipertegas oleh Ismail Yusanto dalam pernyataannya terkait HTI oleh Pemerintah Indonesia di tahun 2017. Saat itu, Ismail menjelaskan bahwa kelompoknya tidak memiliki niat terjun pada dunia politik. Ia menyatakan saat itu bahwa HTI bukan sebagai partai politik dan Ismail menyatakan bahwa memang HT secara bahasa mempunyai makna "partai pembebasan". Ia menguraikanbahwaHTImempunyaikeinginan membuat bebas individu dari memperhamba pada manusia yang diganti dengan memperhamba pada Allah.

Meski mempunyai arti berbeda dengan makna partai politik di Indonesia, Ismail Yusanto melihat bahwa HTI telah sudah menjalankan tiga fungsi partai politik; a. Pendidikan politik, b. agregasi politik, c. artikulasi politik yang dilakukan lewat sejumlah pertemuan dan agenda. (cnnindonesia.com, 2019). Hal tersebut dilakukan oleh HTI sejalan dengan konteks kesadaran politik yang mereka citacitakan, bahwa cara mewujudkannya melalui pemeliharaan politik pada pemahaman yang politis, baik pemeliharaan ideologi dan hukum Islam.

Pada kondisi Indonesia, HT masih sampai di tingkatan tindakan moral politik yang dijalankan pada sejumlah agenda, utamanya lewat tabligh akbar serta aksi demonstrasi. Keduanya adalah bentuk HT mengaspirasikan ide politik Islam. Bagi HTI, mereka akan terus memperjuangkan konsep pemerintahan Islam meski baru berkarakter ekstra parlementer, melalui kegiatan seminar dialog, bentuk diskusi, tabligh akbar, aksi demonstrasi dan rapat-rapat secara general (Jonkennedi, 2012).

HTI termasuk aktif dalam mengkritik dan menentang berbagai kebijakan pemerintah yang menyimpang dari Islam serta memperjuangkan agenda-agenda politik yang mengarah pada sistem Islami. Selain melalui sarana-sarana pertemuan dengan masyarakat luas dan media massa, mereka juga aktif berdemonstrasi menentang berbagai kebijakan pemerintah yang dianggap menyimpang, sekaligus mendesakkan tuntutan-tuntutan yang sesuai dengan pemikiran HTI.

HT memiliki visi umum "Mendirikan Khilafah Islamiyah" dan visi khusus "Menjadi partai politik yang berideologi Islam (gerakan dakwah melalui perjuangan politik). Untuk itu HT memiliki misi (1) menyeru pada kebajikan, yang merupakan ajakan menuju Islam dan (2) mengajak pada hal yang baik dan menangkal hal yang munkar. Sarana yang digunakan HT untuk menerapkan sistem hukum Islam adalah kekuasaan (Minardi, 2008).

Sebagai partai pembebasan (Hizbu attahrir), maka HTI secara umum mempunyai 
sejumlah poin dalam organisasinya; Pertama, tidak seperti partai politik kebanyakan, struktur partai dan kepemimpinan HTI bersifat tertutup untuk publik karena hanya bisa diakses oleh anggota. Kedua, HTI tidak menjalankan fungsi penyediaan calon pemimpin atau wakil rakyat karena ia menolak berpartisipasi dalam pemilu. Ketiga, meski pada awalnya didominasi kaum muda dan mahasiswa dari kampus sekuler, namun basis HTI saat ini semakin beragam, baik dari sisi usia, profesi, juga latar belakang sosial ekonomi. Keempat, tiap anggota HTI adalah kader yang sangat ideologis. Dalam berinteraksi dengan kelompok lain, mereka selalu memegang teguh pandangan-pandangan normatif kelompok dan menginginkan agar gagasan-gagasan solusisolusi HTI diterima sebagai jalan keluar berbagai persoalan yang ada (Taqwa, 2015).

Pola gerakan HTI dikatakan oleh Novriantoni Kahar sebagai pola yang tidak biasa, karena memiliki ide politiknamun berbaju ormas. Hal itu pula yang menurut Novri menjadikan HTI mudah masuk kampus dan merekrut anggota. HTI adalah partai yang menyamar menjadi ormas, karena jika memang partai, maka yang berlaku adalah UU Kepartaian dan tidak bisa masuk kampus (Kahar, 2019). Konsep khilafah Islamiyah yang selalu digaungkan oleh HTI membuat pemerintah Indonesia melihat bahwa HTI tidak berpihak terhadap ideologi Pancasila dalam pergerakannya, meski kata Pancasila termaktub dalam AD/ART yang mereka miliki. Hingga akhirnya hal tersebut dinilai oleh pemerintah tidak sejalan dengan ideologi bangsa, dan pemerintah mengeluarkan surat keputusan pembubaran HTI di tahun 2017.

Penyematan anti Pancasila oleh pemerintah pada tubuh HTI, saat itu ditolak oleh Ismail Yusanto sebagai jubir HTI. Ia meminta pada golongan yang menyatakan HTI tidak pro pada Pancasila, untuk memberi bukti atas deklarasinya. Saat itu ia juga menyebut, HTI cuma terdaftar di Kementerian HAM dan tidak terdaftar di Kementerian Dalam Negeri karena memang telah berkenaan pada aturan pasal 12 No. 2 UU No. 17 Tahun 2013 tentang Organisasi Kemasyarakatan. Menurutnya, pendaftaran organisasi kemasyarakatan memang ada di Kementerian Hukum dan HAM, bukan di Kementerian Dalam Negeri sebagaimana amanat pasal yang ada (Kuwado, 2017).

\section{SIMPULAN}

HTIsebagaibagiandarigerakanfundamentalisme Islam berpandangan bahwa konsep demokrasi yang sudah dikenalkan Barat ke pemerintahpemerintah Islam, adalah yang ingkar, serta tidak memiliki kaitan dengan Islam. Demokrasi dikatakan oleh HTI sangat bertentangan dengan hukum Islam. Demokrasi bagi mereka adalah penyebab negara khilafah tidak dapat didirikan, dan masyarakat muslim tidak diperkenankan secara sepenuhnya untuk mengangkat, terlebih menjalankan sistem pemerintahan demokrasi. Khilafah merupakan konsep sentral pemikiran HTI dan merupakan sistem politik yang harus diimplementasikan lagi oleh masyarakat muslim. Terkait politik, HTI mempunyai persentuhan politik dengan pemerintah. Di tahun 2010, HTI menyebarkan tulisan-tulisannya di Buletin AlIslam yang merupakan buletin HTI, dimana mereka menuliskan tentang pelanggaran HAM, haram halal dan lainnya, dengan berakhir pada urgensi bentuk pemerintahan khilafah Islamiyah. HTI juga sempat mengirim surat terbuka pada pemimpin Indonesia saat itu, Susilo Bambang Yudhoyono guna menjalankan sistem khilafah di Indonesia. Sebagi potret bahwa mereka bersifat terbuka dalam politik di tanah air, mereka juga aktif mengkritik dan menentang sejumlah kebijakan pemerintah yang menyimpang dari Islam, dengan diakhiri ajakan terhadap pendirian khilafah Islamiyah.

\section{DAFTAR PUSTAKA}

Amin, A. R. al. (2012). Membongkar Proyek Khilafah Ala Hizbut Tahrir Indonesia. Lkis Pelangi Aksara.

An-Nabhani, T. (2006). Konsepsi Politik Hizbut Tahrir. HTI Press.

Azman. (2018). Gerakan dan Pemikiran Hizbut Tahrir Indonesia. Ad-Daulah; Jurnal Hukum Pidana dan Ketatanegaraan UIN Alauddin, 7(1), 111. http://journal. uin-alauddin.ac.id/index.php/al_daulah/ article/view/5329/pdf

Badrussyamsi. (2015). Fundamentalisme Islam: Kritik atas Barat. Lkis Pelangi Aksara.

cnnindonesia.com. (2019). Menteri Agama: HTI Gerakan Politik, Bukan Gerakan Dakwah. 
Hakim, R. N. (2014). Gerakan Islam Politik Fundamentalis: Kasus Hizbut Tahrir Indonesia di Surabaya. Jurnal Review Politik, 04(Desember), 229. http:// jurnalfuf.uinsby.ac.id/index.php/JRP/ article/download/1016/951/

Held, D. (2006). Models of Democracy. Polity Press.

Hendropriyono, A. . (2009). Terorisme; Fundamentalis Kristen, Yahudi, Islam. Kompas.

Jahroni, J., \& Jamhari. (2004). Gerakan Salafi Radikal di Indonesia,. PT Raja Grafindo Persada.

Jamilah, S. (2020). Gerakan Sosial Islam Hizbut Tahrir: Syarah dan Implementasi Pemikiran Taqiyuddin An-Nabhani di Kota Parepare. Relasi Inti Media.

Jonkennedi. (2012). Gerakan Hizbut Tahrir dan Realitas Politik Islam Kontemporer di Indonesia. Jurnal Dakwah Dan Komunikasi STAIN Purwokerto, Komunika, Vol.6 No.1(Januari-Juni), 4.

Kahar, N. (2019). Gerakan HTI dan Gagasan Politik tentang Khilafah. M.Detik.Com.

Kamil, S. (2013). Islam dan Politik di Indonesia Terkini. Pusat Studi Indonesia dan Arab (PSIA): UIN Syarif Hidayatullah Jakarta.

Kuwado, F. J. (2017). HTI: Coba Tunjukkan, di Mana Kami Sebut Anti-Pancasila. Kompas.Com. https://nasional.kompas. com/read/2017/05/03/08382391/hti. coba.tunjukkan.di.mana.kami.sebut.antipancasila.?page $=$ all

M.merdeka.com. (2019). Di AD/ART HTI, Ideologi yang dicantumkan Pancasila tapi diingkari.
Minardi,A. (2008). Konsep Negara dan Gerakan Baru Islam Menuju Negara Modern Sejahtera; Pemikiran Politik Revivalis Islam Partai Keadilan Sejahtera dan Hizbut Tahrir. Prisma Press Prodaktama.

Muhtadi, B. (2009). The Quests for Hizbut Tahrir in Indonesia. Asian Journal of Social Science, 37, 641-642. https://brill.com/ view/journals/ajss/37/4/article-p623_5. $\mathrm{xml}$ ?language $=\mathrm{en}$

Rahardjo,M.D.(2010).MerayakanKemajemukan Kebebasan dan Kebangsaan. Kencana.

Rahmat, M. I. (2008). Ideologi Politik PKS; Dari Masjid Kampus ke Gedung Parlemen. LKis.

Redaksi. (2007). Khilafah vis a vis Nasionalisme. Ayok.Wordpress.Com. https://ayok. wordpress.com/2007/07/18/khilafah-visa-vis-nasionalisme/

Shobron, S. (2014). Model Dakwah Hizbut Tahrir Indonesia. PROFETIKA; Jurnal Studi Islam, 15(No.1, Juni), 52. http:// journals.ums.ac.id/index.php/profetika/ article/download/1966/1379

Sorensen, G. (2003). Demokrasi dan Demokratisasi,. Pustaka Pelajar.

Sukardja, A., \& Sudirman, A. (2005). Demokrasi dalam Perspektif Islam. Pedoman Ilmu Jaya dengan Anglo Media Jakarta.

Sumbulah,U.(2009). Konfigurasi Fundamentalisme Islam. UIN Malang Press.

Taqwa, L. (2015). Evolusi Gerakan HTI dan Ancaman terhadap Generasi Muda Islam. Jurnal Review Politik UIN Surabaya, Vol.5 No.1(Juni), 8.

Yusanto, M. I. (n.d.-a). Islam dan Demokrasi.

Yusanto, M. I. (n.d.-b). Wawancara. 